\title{
The Balancing of the Sea-Level Budget
}

\author{
Eric W. Leuliette ${ }^{1}$
}

Published online: 9 May 2015

(C) Springer International Publishing AG (outside the USA) 2015

\begin{abstract}
The last 5 years have seen continued progress in closing the sea-level budget, the accounting for the contributions of sea-level change, during the late twentieth and early twenty-first centuries. Balancing the sea-level budget is critical to understanding recent and future climate change as well as balancing the Earth's energy budget and water budget. During the last decade, advancements in the ocean observing system - satellite altimeters, hydrographic profiling floats, and space-based gravity missions - have allowed the sea-level budget to be assessed with unprecedented accuracy from direct, rather than inferred, estimates. In particular, several recent studies have used the sea-level budget to bound the rate of deep-ocean warming. Despite the fact that much of the observing system in place before the satellite era was not intended for global climate monitoring, new analyses of the historical record suggest that the twentieth century sea-level budget may be understood.
\end{abstract}

Keywords Sea level · Argo · GRACE · Altimetry

\section{Introduction}

Among the many measurements of the Earth's climate, sealevel change is prominent both for its direct impact on human

This article is part of the Topical Collection on Sea Level Projections

Eric W. Leuliette

Eric.Leuliette@noaa.gov

1 Laboratory for Satellite Altimetry, NOAA Center for Satellite Applications and Research, NOAA Center for Weather and Climate Prediction (E/RA), 5830 University Research Court, College Park, MD 20740, USA activities and as an indicator of climatic change. The ocean is overwhelmingly the major reservoir for the storage of extra heat that has been added to the climate system as well as the water mass lost from melting ice sheets and glaciers. Worldwide, hundreds of millions of people live in coastal zones, and rising seas and their accompanying impacts-flooding, saltwater intrusion, and habitat loss - will increasingly burden the affected societies [1]. With the expectation that sea-level rise will continue to accelerate over the next century, a robust system for monitoring sea-level rise, as well as measuring its causes, is vital.

Instrumental to demonstrating the integrity of climate monitoring is the concept of an observational budget. Because of the conservation of energy or mass, it should be possible to completely account for the exchange of heat, water, or other matter by fluxes from one reservoir to another in the climate system. In the case of sea level, the budget is often accounted in units of global mean sea level, a reflection of incremental increases or decreases of the volume of water in the global ocean. Changes in the volume of the ocean are inferred by observing variations in globally averaged sea level and by modeling the changes in the shape of the ocean basin that are caused by geophysical processes. One millimeter of global mean sea-level change is equivalent to $361 \mathrm{~km}^{3}$ of volume change. The goal, therefore, in the exercise of determining the sea-level budget is to confirm that observations of changes in sea level during a particular time period match the sum of the measurements of the component causes of sea-level change [2].

On decadal time scales, the individual causes of volume change in the ocean are two processes, density (steric) changes and the water exchange between the ocean and continents [2]. Changes in ocean temperature and salinity produce density changes, which are inversely proportional to volume changes. When expressed as a component of mean sea level, this effect 
is termed steric sea level. Temperature changes are equivalent to ocean heat content changes. The exchange of water between the ocean and reservoirs of continental hydrology (ice sheets, glaciers, ice caps, groundwater, and inland surface waters) results in variations in the ocean's total mass. This component is sometimes called barystatic sea level [3•].

To meaningfully interpret the causes of sea-level change during a particular period, the budget must be closed. In other words, changes in observed sea level should be equal to the sum of the changes attributable to density changes and water mass exchange, or observed total sea-level changes should be the sum of steric and barystatic sea level. This closure implies that the observations are complete and accurate.

The sea-level budget is intimately related to other important climate system budgets (Fig. 1). The conservation of water mass in the hydrological cycle requires that all water exchanged between the land (and to a much lesser extent the atmosphere) and the ocean should be accounted for by observations. Similarly, the oceans play a dominant role in accounting for the Earth's energy budget (also known as the Earth's radiation balance), which describes the net flow of energy into the Earth in the form of shortwave radiation and outgoing infrared long-wave radiation. The ocean accounts for over $90 \%$ of the changes in global heat storage, with terrestrial and atmospheric reservoirs of heat being far less important $[4,5]$. Arguably, closing the sea-level budget to within appropriate confidence intervals is essential to the closing of the global energy and the hydrological budgets.

\section{Observations of Sea Level and Its Components}

International collaborations in recent years have implemented a global ocean observing system that monitors the variability of not only total sea level but also the major contributions to sea-level change. The combination of contemporaneous

\section{Sea level budget}

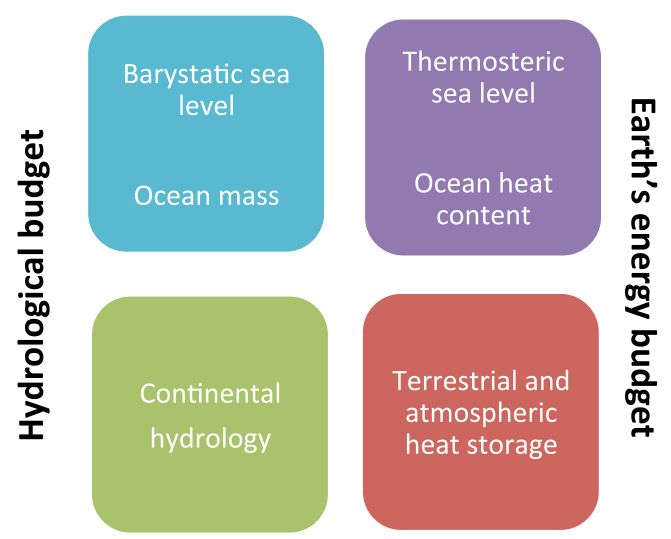

Fig. 1 The relationship between the sea-level budget, the Earth's energy budget, and the hydrological cycle measurements from this observing system - satellite altimeters, hydrographic profiling floats, and space-based gravity missions - allows the observational sea-level budget to be assessed from direct, rather than inferred, estimates. Sealevel datasets from earlier eras are from measuring systems not designed for global climate monitoring. Reconstructing the sea-level record for at least the entire twentieth century is critical to understanding multidecadal variability. The sealevel budget has been a valuable metric in assessing the completeness and accuracy of these historical reanalyses of steric, barystatic, and total sea levels.

\section{Total Sea Level}

The sea level observing system has evolved from intermittent records of sea level at four sites in Northern Europe starting in the 1700 s to nearly complete and regular coverage by satellite altimeters and a geodetically monitored network of tide gauges in the 1990s. By the late 1800s, tide gauges were in operation in Northern Europe, on both North American coasts, and in Australia and New Zealand in the Southern Hemisphere. In the early twentieth century, tide gauges began to be installed on islands far from continental coasts. Not until the 1970s did a majority of deep-ocean islands have an operating tide gauge suitable. Analyses of twentieth century global mean sea level (GMSL) using tide gauge records have employed different methods to accommodate the spatially sparse, temporally incomplete sampling of global sea level by gauges, which potentially introduces significant biases into estimates of GMSL. Most of these have concluded that GMSL rose over the twentieth century at a mean rate of 1.6 to $1.9 \mathrm{~mm} /$ year [6-12]. However, two recent studies suggest a somewhat slower trend. Woppelmann et al. [13] extrapolated contemporary land motion corrections at gauges into the past [14] and found a rate of $1.5 \pm 0.5 \mathrm{~mm} /$ year after area-weighting trends in the northern and southern hemispheres. Hay et al. [15•] use a Kalman smoothing reconstruction [16] that uses the spatial patterns inherent to the individual physical processes driving sea-level change to infer weights for the gauges. They find a significant rate of GMSL rise from 1901 to 1990, $1.2 \pm 0.2 \mathrm{~mm} /$ year $(90 \% \mathrm{CI})$ slower than the rate in the IPCC Fifth Assessment Report for the same period, $1.5 \pm 0.2 \mathrm{~mm} /$ year [39].

Sea level has been continuously monitored since 1992 by satellite radar altimeters (e.g., TOPEX/Poseidon, Jason-1, Jason-2, and Envisat) with sufficient accuracy and stability to monitor regional and global trends. Estimates of the straightline trend in GMSL from 1992 to 2013 are higher than the presatellite twentieth century rate, $3.1 \pm 0.4 \mathrm{~mm} /$ year $(90 \% \mathrm{CI})$ $[17,18]$. Different studies of trends in the GMSL record from altimetry show close agreement despite differences in interannual variability resulting from processing choices $[19,20]$. Monthly, the global mean sea-level change can be monitored 
with errors around $2 \mathrm{~mm}$. Drifts in sea-level estimates from altimetry can be detected using a network of tide gauges [21, 22]. Reported tide gauge comparisons for the combined record from TOPEX/Poseidon, Jason-1, and Jason-2 are consistent with no significant drift [22-26]. The comparison technique is limited mainly by the availability and accuracy of land motion corrections at the gauges and may be capable of detecting drifts $>0.4 \mathrm{~mm} /$ year.

\section{Steric Sea Level}

Steric (density) sea-level changes are largely a response to changes in temperature with local contributions from salinity. Much of the historical record of the subsurface prior to 2000 is from bathythermographs, measuring only heat content or, equivalently, the thermosteric component of sea level due to thermal expansion of sea water. Routine observations beginning in the 1960s gradually transitioned from mechanical to more precise electronic instruments. By the late 1960s expendable bathythermographs (XBTs) released from ships of opportunity contributed the majority of subsurface temperature measurements. However, XBTs were not designed for climate measurements. XBT sampling depths are not measured from pressure, but are inferred from the estimated fall rate, and uncertainties in the fall rate, manufacturing variations, and other issues caused some reported XBT temperatures to be biased.

More recently, estimates of steric sea-level variations in the upper ocean are obtained from the global array of the Argo project [2, 27-34]. Argo deployments of autonomous hydrographic profiling floats that measure both temperature and salinity began in 2000 . In November 2007 , the array surpassed 3000 active floats, achieving a sampling of approximately every three degrees of latitude and longitude over 10 days [35]. Now, with more than 3500 active floats, Argo creates a more uniform distribution than historical observations, providing dramatically improved coverage of the upper $700 \mathrm{~m}$ and increasingly the upper $2000 \mathrm{~m}$ of the global ocean, particularly in the Southern Hemisphere [36]. On a monthly basis, the global mean steric sea-level change from Argo in the upper ocean can be found with errors around $3 \mathrm{~mm}$, with the error decreasing over time as more floats sample to $2000 \mathrm{~m}$ with fewer biases [28, 37]. Some studies have suggested that Argo data are best suited for global analyses of upper ocean steric changes only after 2005 due to a combination of interannual variability and significant biases when using earlier data due to sparser and shallower sampling [28, 34].

The fifth assessment report of the IPCC [38, 39] concluded that upper ocean measurements were too sparse before 1971 to estimate trends in thermosteric sea level. The warming of the upper $700 \mathrm{~m}$ from 1971 to 2010 caused an estimated mean thermosteric rate of rise of $0.6 \pm 0.2 \mathrm{~mm} /$ year $(90 \% \mathrm{CI}), 50 \%$ higher than previous estimates $[27,40 \bullet, 41]$. Observations of the contribution to sea-level rise from warming below $700 \mathrm{~m}$ are more uncertain due to limited historical data and are usually based on 5-year averages to 2000-m depth [33]. From 1971 to 2010, the estimated trend for the contribution between 700 and $2000 \mathrm{~m}$ is $0.1 \pm 0.1 \mathrm{~mm} /$ year $(90 \% \mathrm{CI})$ [33]. To measure the contribution of warming below $2000 \mathrm{~m}$, much sparser but very accurate temperature profiles along repeat hydrographic sections are used [42-44]. The studies have found a significant warming trend between 1000 and $4000 \mathrm{~m}$ within and south of the Sub-Antarctic Front. The estimated total contribution of warming below $2000 \mathrm{~m}$ to global mean sea-level rise between circa 1992 and 2005 is $0.1 \pm 0.1 \mathrm{~mm} /$ year $(95 \% \mathrm{CI})$ [44].

\section{Ocean Mass/Barystatic Sea Level}

Broadly speaking, four approaches have been used to infer or directly measure changes in barystatic sea level. In one approach, all changes in continental water storage is estimated [4], including the melting of the Greenland and Antarctic ice sheets, mountain glaciers and ice caps, changes in dam retention, the depletion of groundwater, and natural variability of terrestrial surface waters $[45,46]$. Any net change in the sum of these reservoirs is assumed to be an exchange of freshwater with the ocean. In another approach, the rate of barystatic sea level is inferred from freshening of the ocean (i.e., decreases in mean salinity), if the contribution from melting of sea ice, which affects freshening but not sea level, can be estimated [47-49]. A more recent approach exploits so-called sea-level fingerprints, which are regional patterns in sea-level change that result from the deformation of the solid Earth and the changes in the Earth's gravitational field in response to ice sheets gaining or losing mass and water exchange between the continents and the ocean [50]. For example, sea-level measurements from tide gauges can be used to solve for "fingerprints" and infer the individual contributions to sea level [16]. Lastly, changes in time-varying gravity observed from space missions such as the Gravity Recovery and Climate Experiment (GRACE) are used to observe changes in ocean mass after using models to remove the variations of atmospheric mass and the effects of glacial isostatic adjustment (see below) [15•]. Additionally, GRACE can be used to measure changes in continental hydrology and can potentially close the hydrological cycle by tracking the exchange of freshwater between the continents and ocean.

\section{The Role of Geodesy and Geophysics}

Geophysical processes of the solid Earth affect several measurements from the observing system related to sea level. At the most basic level, to close the sea-level budget, all measurements must be made in a common terrestrial reference frame, 
Table 1 Global mean sea-level budget over different time intervals from observations, adapted from [39], Table 13.1, except where noted

\begin{tabular}{|c|c|c|c|c|}
\hline Source & $1901-1990$ & $1971-2010$ & $1993-2010$ & $2005-2013[64 \cdot, 65]$ \\
\hline \multicolumn{5}{|c|}{ Observed contributions to global mean sea-level (GMSL) rise in millimeter/year (95\% CI) } \\
\hline Thermal expansion & - & $0.8 \pm 0.3$ & $1.1 \pm 0.3$ & $1.0 \pm 0.5$ \\
\hline Glaciers except in Greenland and Antarctica & $0.54 \pm 0.07$ & $0.62 \pm 0.37$ & $0.76 \pm 0.37$ & - \\
\hline Glaciers in Greenland & $0.15 \pm 0.05$ & $0.06 \pm 0.03$ & $0.10 \pm 0.03$ & - \\
\hline Greenland ice sheet & - & - & $0.33 \pm 0.08$ & - \\
\hline Antarctic ice sheet & - & - & $0.27 \pm 0.11$ & - \\
\hline Land water storage & $-0.11 \pm 0.05$ & $0.12 \pm 0.10$ & $0.38 \pm 0.12$ & - \\
\hline Ocean mass/barystatic from GRACE & - & - & - & $2.0 \pm 0.2$ \\
\hline Total of contributions & - & - & $2.8 \pm 0.6$ & $3.0 \pm 0.5$ \\
\hline Observed GMSL rise & $\begin{array}{l}\mathbf{1 . 5} \pm \mathbf{0 . 2 1} \\
\mathbf{1 . 2} \pm \mathbf{0 . 2}\end{array}$ & $2.0 \pm 0.3$ & $3.2 \pm 0.4$ & $3.0 \pm 0.4$ \\
\hline
\end{tabular}

The bold entries were meant to highlight the lines for total sea level to aid comparison

the International Terrestrial Reference System (ITRS). The global networks for the four major precise positioning systemssatellite laser ranging, GNSS, VLBI, and DORIS - form the backbone of the observing system by providing continuous monitoring of the International Terrestrial Reference Frame (ITRF).

Terrestrial land motion in the vertical must be removed from tide gauge levels to translate relative sea level measured with respect to the continental crust into a volume or mass change needed for sea-level budget. In addition, land motion effects must be removed from elevation changes in the cryosphere to compute land ice changes from ice sheets and glaciers [51]. These land motions include tectonic deformations from earthquakes and plate motion, subsidence from water or resource extraction, and the responses to the removal of ice and liquid water loads. The responses to load changes are particularly important when estimating the sea-level budget. The first is a nearly instantaneous, elastic response of the Earth due to contemporary load changes (e.g., melting ice sheets). The second is the time-delayed, viscous response due to past load changes from the last ice age, glacial isostatic adjustment (GIA). After some confusion about the appropriate methodology necessary to compute the GIA effect on ocean mass estimates from GRACE [52-55], model predictions of the GIA effects on tide gauges (relative sea level), altimetry (geocentric sea level or the sea surface), the time-varying geoid as measured by GRACE, and crustal motion are available for sea-level budget studies [51, 56, 57].

In the global mean, GIA produces a small net sinking of the ocean floor relative to the Earth's center, which, if the sea surface did not change, would imply a small secular increase in volume, which geophysical modeling suggests is 75 to $180 \mathrm{~km}^{3} /$ year. Therefore, the rate of GMSL observed by altimeters is higher by $+0.3 \mathrm{~mm} /$ year when GMSL is expressed as a change in ocean volume [58]. Similarly, GIA effects must be removed from GRACE observations of changes in the geoid in order to isolate ocean mass variations [52]. While the GIA signal for altimetry reflects changes in ocean volume, the GIA correction for ocean mass variations from GRACE accounts for mass redistribution from crustal motion, which produces significantly larger apparent changes in terms of equivalent water height, roughly $1 \mathrm{~mm} /$ year.

\section{Recent Progress in Sea-Level Budget Closure}

The current state of knowledge of the sea-level budget is summarized in Table 1, adapted largely from [39], Table 13.1. Surprisingly, sea-level rise since the early 1990s has progressed at a relatively constant rate, despite evidence of acceleration in the melting of mountain glaciers and ice sheets in Greenland and Antarctica. The resulting acceleration in the rate of ocean mass increase appears to have been somewhat compensated by a decrease in the rate of steric rise due to thermal expansion [2]. There have been departures from a straight-line trend, associated mainly with ENSO variability $[59,60]$. The sea-level budget and GRACE observations were able to confirm that the significant decrease in mean sea level from 2010 to the middle of 2011 was due to a large increase in

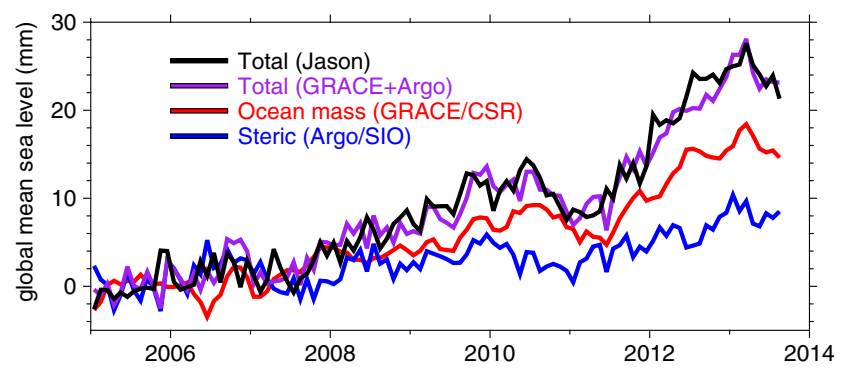

Fig. 2 Monthly estimates from Jason-1 and Jason-2 of global mean sea level (black), which are in general agreement with the sum (purple) of the ocean mass component from the Gravity Recovery and Climate Experiment, GRACE (red), and the steric component of the upper $2000 \mathrm{~m}$ from Argo (blue) from Leuliette [65]. Seasonal signals have been removed 
water storage in northern South America and Australia [61]. Further study indicated that the longevity of the anomaly could be attributed to water storage in closed drainage basins in Australia [62].

On a monthly basis, the sum of the steric component estimated from Argo and the barystatic component from GRACE agree with total sea level from Jason within the estimated uncertainties (Fig. 2), with the residual difference having less than $4 \mathrm{~mm}$ [65]. Direct measurements of ocean warming above 2000-m depth during January 2005 and December 2013 explain about one third of the observed annual rate of global mean sea-level rise. While some recent budget studies infer a significant contribution to recent global sea-level rise from deep-ocean warming [63], direct observations accounting for systematic uncertainties find that the deep ocean (below $2000 \mathrm{~m}$ ) contributes only $-0.13 \pm 0.72 \mathrm{~mm} /$ year to global sea-level rise [64•].

Purkey et al. [43] use the sea-level budget to estimate regional and global trends of sea level due to ocean mass changes using a residual method (the difference between altimetry and full-depth in situ ocean data) between 1996 and 2006 and directly estimated from the GRACE during 2003 to 2013. Both methods capture the same large-scale mass addition trend patterns, including higher rates of mass addition in the North Pacific, South Atlantic, and the Indo-Atlantic sector of the Southern Ocean, and lower ocean mass trends in the Indian, North Atlantic, South Pacific, and the Pacific sector of the Southern Ocean.

\section{Conclusion}

As the climate continues to warm, sustained observations to monitor changes in global sea level and its causes will remain as important priorities. While warming of the ocean over the century will continue to cause sea-level rise from thermal expansion, loss of ice from Greenland and Antarctica, already the dominant contribution to total rise, is expected to accelerate. Over the last decade, the spatial pattern of sea-level change has been dominated by steric changes and winddriven redistribution, but as the contribution from ocean mass becomes larger, very different patterns are expected.

The sea-level climate data record from altimetry will continue with new reference missions with sufficient stability to monitor sea-level rise: Jason-3 and Jason-CS/Sentinel-6, which are planned for launches in 2015 and 2020, respectively. The instruments on the GRACE satellites have operated several years beyond their nominal mission design. In order to prevent or shorten a significant gap in observations, a followon mission is planned for late 2017. The Argo array will need continual replacement of floats to maintain the network, as well as the development and deployment of Deep Argo floats capable of monitoring changes in the abyssal ocean.
Extending the understanding of the historical budget from global mean sea level to regional patterns of sea-level change will require interdisciplinary research. For example, we do not yet have a thorough understanding of past and future changes in low-frequency spatial redistribution of water [66, 67]. Until ocean reanalyses begin assimilating tide gauge observations and the geophysical response of the solid Earth along with historical ocean databases, we will lack a fuller understanding of twentieth century sea-level rise [68].

Acknowledgments The views, opinions, and findings contained in this paper are those of the authors and should not be construed as an official NOAA or US Government position, policy, or decision. The author thanks the anonymous reviewer for valuable comments and suggestions. The altimeter data is from the Radar Altimeter Database System (http:// rads.tudelft.nl/). The GRACE data are available at http://podaac.jpl.nasa. gov/grace. The GIA corrections [51] are from http://grace.jpl.nasa.gov. The Argo results were computed from the Roemmich-Gilson Argo Climatology [69]. The figures were produced with the Generic Mapping Tools [70].

\section{Compliance with Ethics Guidelines}

Conflict of Interest On behalf of all authors, the corresponding author states that there is no conflict of interest.

Human and Animal Rights and Informed Consent This article does not contain any studies with human or animal subjects performed by any of the authors.

\section{References}

Papers of particular interest, published recently, have been highlighted as:

- Of importance

1. Nicholls R. Planning for the impacts of sea level rise. Oceanography. 2011;24:144-57. doi:10.5670/oceanog.2011.34.

2. Leuliette E, Willis J. Balancing the sea level budget. Oceanography. 2011;24:122-9. doi:10.5670/oceanog.2011.32.

3. Gregory JM, White NJ, Church JA, et al. Twentieth-century globalmean sea level rise: is the whole greater than the sum of the parts? J Clim. 2013;26:4476-99. doi:10.1175/JCLI-D-12-00319.1. Using observations and computer simulations, this paper attempts to reconstruction the sea level budget during 20 th century account for the near-constant of the rate of global mean sea level rise.

4. Church JA, White NJ, Konikow LF, et al. Revisiting the Earth's sea-level and energy budgets from 1961 to 2008. Geophys Res Lett. 2011. doi:10.1029/2011GL048794.

5. Church JA, White NJ, Konikow LF, et al. Correction to "Revisiting the Earth's sea-level and energy budgets from 1961 to 2008.". Geophys Res Lett. 2013;40:4066. doi:10.1002/grl.50752.

6. Douglas BC. Global sea level rise. J Geophys Res. 1991;96:698192. doi:10.1029/91JC00064.

7. Douglas B. Global sea rise: a redetermination. Surv Geophys. 1997;18:279-92. doi:10.1023/A:1006544227856. 
8. Holgate S. On the decadal rates of sea level change during the twentieth century. Geophys Res Lett. 2007;34, L01602. doi:10. 1029/2006GL028492.

9. Jevrejeva S, Moore JC, Grinsted A, Woodworth PL. Recent global sea level acceleration started over 200 years ago? Geophys Res Lett. 2008;35, L08715. doi:10.1029/2008GL033611.

10. Church JA, White NJ. Sea-level rise from the late 19th to the early 21 st century. Surv Geophys. 2011;32:585-602. doi:10.1007/ s10712-011-9119-1.

11. Ray RD, Douglas BC (2011) Experiments in reconstructing twentieth-century sea levels. Progress in Oceanography 1-20. doi: 10.1016/j.pocean.2011.07.021

12. Wenzel M, Schröter J. Reconstruction of regional mean sea level anomalies from tide gauges using neural networks. J Geophys Res. 2010;115, C08013. doi:10.1029/2009JC005630.

13. Wöppelmann G, Marcos M, Santamaría-Gómez A, et al. Evidence for a differential sea level rise between hemispheres over the twentieth century. Geophys Res Lett. 2014;41:1639-43. doi:10.1002/ 2013 GL059039.

14. Santamaría-Gómez A, Gravelle M, Collilieux X, et al. Mitigating the effects of vertical land motion in tide gauge records using a state-of-the-art GPS velocity field. Glob Planet Chang. 2012;9899:6-17. doi:10.1016/j.gloplacha.2012.07.007.

15. Hay CC, Morrow E, Kopp RE, Mitrovica JX. Probabilistic reanalysis of twentieth-century sea-level rise. Nature. 2015. doi:10.1038/ nature 14093. This paper presents an analysis of the 20th century sea level record from tide gauges using a modified multi-model Kalman smoother (KS). The KS analysis exploits non-uniform patterns ("fingerprint") in sea level attributable to the individual contributions from melting glaciers and ice sheets.

16. Hay CC, Morrow E, Kopp RE, Mitrovica JX. Estimating the sources of global sea level rise with data assimilation techniques. Proc Natl Acad Sci. 2012. doi:10.1073/pnas.1117683109.

17. Cazenave A, Dieng H-B, Meyssignac B, et al. The rate of sea-level rise. Nat Clim Chang. 2014. doi:10.1038/nclimate2159.

18. Merrifield, MA, Thompson, P, Leuliette E, et al. State of the Climate in 2013. 2014; 95:S1-S279. doi: 10.1175/ 2014BAMSStateoftheClimate.1

19. Masters D, Nerem RS, Choe C, et al. Comparison of global mean sea level time series from TOPEX/Poseidon, Jason-1, and Jason-2. Mar Geod. 2012;35:20-41. doi:10.1080/01490419.2012.717862.

20. Henry O, Ablain M, Meyssignac B, et al. Effect of the processing methodology on satellite altimetry-based global mean sea level rise over the Jason-1 operating period. J Geod. 2013;88:351-61. doi:10. 1007/s00190-013-0687-3.

21. Mitchum GT. Monitoring the stability of satellite altimeters with tide gauges. J Atmos Ocean Technol. 1998;15:721-30. doi:10. 1175/1520-0426(1998)015<0721:MTSOSA >2.0.CO;2.

22. Mitchum GT. An improved calibration of satellite altimetric heights using tide gauge sea levels with adjustment for land motion. Mar Geod. 2010;23:145-66. doi:10.1080/01490410050128591.

23. Leuliette EW, Scharroo R. Integrating Jason-2 into a multiplealtimeter climate data record. 2010; 33:504-517. doi: 10.1080/ 01490419.2010 .487795

24. Nerem R, Chambers D, Choe C, Mitchum G. Estimating mean sea level change from the TOPEX and Jason altimeter missions. Mar Geod. 2010;33:435-46. doi:10.1080/01490419.2010.491031.

25. Beckley B, Zelensky N, Holmes S, et al. Assessment of the Jason-2 Extension to the TOPEX/Poseidon, Jason-1 sea-surface height time series for global mean sea level monitoring. Mar Geod. 2010;33: 447-71. doi:10.1080/01490419.2010.491029.

26. Valladeau G, Legeais JF, Ablain M, et al. Comparing altimetry with tide gauges and Argo profiling floats for data quality assessment and mean sea level studies. Mar Geod. 2012;35:42-60. doi:10. 1080/01490419.2012.718226
27. Domingues $\mathrm{C}$, Church J, White $\mathrm{N}$, et al. Improved estimates of upper-ocean warming and multi-decadal sea-level rise. Nature. 2008;453:1090-3. doi:10.1038/nature0708010.1038/nature07080.

28. Leuliette EW, Miller L. Closing the sea level rise budget with altimetry, Argo, and GRACE. Geophys Res Lett. 2009;36, L04608. doi:10.1029/2008GL036010.

29. Willis J. Closing the globally averaged sea level budget on seasonal to interannual time scales. 2007; 1-28.

30. Cazenave A, Dominh K, Guinehut S, et al. Sea level budget over 2003-2008: a reevaluation from GRACE space gravimetry, satellite altimetry and Argo. Glob Planet Chang. 2009;65:83-8. doi:10. 1016/j.gloplacha.2008.10.004.

31. Von Schuckmann K, Gaillard F, Le Traon P-Y. Global hydrographic variability patterns during 2003-2008. J Geophys Res. 2009;114, C09007. doi:10.1029/2008JC005237.

32. Chambers DP, Willis JK. A global evaluation of ocean bottom pressure from GRACE, OMCT, and steric-corrected altimetry. J Atmos Ocean Technol. 2010;27:1395-402. doi:10.1175/ 2010JTECHO738.1.

33. Levitus S, Yarosh ES, Zweng MM, et al. World ocean heat content and thermosteric sea level change (0-2000), 1955-2010. Geophys Res Lett. 2012. doi:10.1029/2012GL051106.

34. Von Schuckmann K, Le Traon P-Y. How well can we derive Global Ocean Indicators from Argo data? Ocean Sci. 2011;7:783-91. doi: 10.5194/os-7-783-2011.

35. Giglio D, Roemmich D. Climatological monthly heat and freshwater flux estimates on a global scale from Argo. J Geophys Res Oceans. 2014. doi:10.1002/2014JC010083.

36. Lyman J, Johnson G. Estimating annual global upper-ocean heat content anomalies despite irregular in situ ocean sampling*. J Clim. 2008;21:5629-41. doi:10.1175/2008JCLI2259.1.

37. Willis JK, Chambers DP, Nerem RS. Assessing the globally averaged sea level budget on seasonal to interannual timescales. J Geophys Res. 2008;113, C06015. doi:10.1029/2007JC004517.

38. Rhein M, Rintoul SR, Aoki S, et al. Observations: Ocean. In: Stocker TF, Qin D, Plattner GK, et al., editors. Climate change 2013: the physical science basis. Contribution of Working Group I to the Fifth Assessment Report of the Intergovernmental Panel on Climate Change. Cambridge, United Kingdom and New York, NY, USA: Cambridge University Press; 2013. p. 255-316.

39. Church JA, Clark PU, Cazenave A, et al. Sea Level Change. In: Stocker TF, Qin D, Plattner GK, et al., editors. Climate change 2013: the physical science basis. Contribution of Working Group I to the Fifth Assessment Report of the Intergovernmental Panel on Climate Change. Cambridge, United Kingdom and New York, NY, USA: Cambridge University Press; 2013. p. 1137-216.

40. Abraham JP, Baringer M, Bindoff NL, et al. A review of global ocean temperature observations: Implications for ocean heat content estimates and climate change. Rev Geophys. 2013;51:450-83. doi: 10.1002/rog.20022. This review paper includes the latest estimates of ocean heat content and the thermosteric component of recent sea level rise.

41. Johnson G, Wijffels S. Ocean density change contributions to sea level rise. Oceanography. 2011;24:112-21. doi:10.5670/oceanog. 2011.31.

42. Kouketsu S, Doi T, Kawano T, et al. Deep ocean heat content changes estimated from observation and reanalysis product and their influence on sea level change. J Geophys Res. 2011;116, C03012. doi:10.1029/2010JC006464.

43. Purkey SG, Johnson GC, Chambers DP. Relative contributions of ocean mass and deep steric changes to sea level rise between 1993 and 2013. J Geophys Res Oceans. 2014;119:7509-22. doi:10.1002/ 2014JC010180.

44. Purkey SG, Johnson GC. Warming of global abyssal and deep Southern Ocean waters between the 1990s and 2000s: contributions 
to global heat and sea level rise budgets. J Clim. 2010;23:6336-51. doi:10.1175/2010JCLI3682.1.

45. Syed TH, Famiglietti JS, Chambers DP, et al. Satellite-based globalocean mass balance estimates of interannual variability and emerging trends in continental freshwater discharge. Proc Natl Acad Sci. 2010. doi:10.1073/pnas.1003292107.

46. Jensen L, Rietbroek R, Kusche J. Land water contribution to sea level from GRACE and Jason-1 measurements. J Geophys Res Oceans. 2013;118:212-26. doi:10.1002/jgrc. 20058.

47. Munk W. Ocean freshening, sea level rising. Science. 2003;300: 2041-3. doi:10.1126/science.1085534.

48. Wadhams P, Munk W. Ocean freshening, sea level rising, sea ice melting. Geophys Res Lett. 2004;31, L11311. doi:10.1029/ 2004GL020039.

49. Munk W. Twentieth century sea level: an enigma. Proc Natl Acad Sci U S A. 2002;10:6550-5. doi:10.1073/pnas.092704599.

50. Rietbroek R, Brunnabend S-E, Kusche J, Schröter J (2011) Resolving sea level contributions by identifying fingerprints in time-variable gravity and altimetry. Journal of Geodynamics 110. doi: 10.1016/j.jog.2011.06.007

51. Geruo A, Wahr J, Zhong S. Computations of the viscoelastic response of a 3-D compressible Earth to surface loading: an application to Glacial Isostatic Adjustment in Antarctica and Canada. Geophys J R Astron Soc. 2013;192:557-72. doi:10.1093/gji/ ggs030.

52. Peltier WR (2009) Closure of the budget of global sea level rise over the GRACE era: the importance and magnitudes of the required corrections for global glacial isostatic adjustment. Quaternary Science Reviews 1-17. doi: 10.1016/j.quascirev.2009. 04.004

53. Peltier WR, Drummond R, Roy K. Comment on "Ocean mass from GRACE and glacial isostatic adjustment" by D. P. Chambers et al. J Geophys Res. 2012;117, B11403. doi:10.1029/2011JB008967.

54. Chambers DP, Wahr J, Tamisiea ME, Nerem RS. Ocean mass from GRACE and glacial isostatic adjustment. J Geophys Res. 2010;115, B11415. doi:10.1029/2010JB007530.

55. Chambers DP, Wahr J, Tamisiea ME, Nerem RS. Reply to comment by W. R. Peltier et al. on "Ocean mass from GRACE and glacial isostatic adjustment.”. J Geophys Res. 2012;117, B11404. doi:10. 1029/2012JB009441.

56. Tamisiea M, Mitrovica J. The moving boundaries of sea level change: understanding the origins of geographic variability. Oceanography. 2011;24:24-39. doi:10.5670/oceanog.2011.25.

57. Tamisiea ME, Hughes CW, Williams SDP, Bingley RM. Sea level: measuring the bounding surfaces of the ocean. Philos Trans R Soc
A Math Phys Eng Sci. 2014;372:20130336. doi:10.1098/rsta.2013. 0336.

58. Douglas B, Peltier W. The puzzle of global sea-level rise. Phys Today. 2002;55:35-40. doi:10.1063/1.1472392.

59. Nerem R, Chambers D, Leuliette E, et al. Variations in global mean sea level associated with the 1997-1998 ENSO event: implications for measuring long-term sea level change. Geophys Res Lett. 1999;26:3005-8. doi:10.1029/1999GL002311.

60. Cazenave A, Llovel W. Contemporary sea level rise. Annu Rev Mar Sci. 2010;2:145-73. doi:10.1146/annurev-marine-120308-081105.

61. Boening C, Willis JK, Landerer FW, et al. The 2011 La Niña: so strong, the oceans fell. Geophys Res Lett. 2012;39, L19602. doi:10. 1029/2012GL053055.

62. Fasullo JT, Boening C, Landerer FW, Nerem RS. Australia's unique influence on global sea level in 2010-2011. Geophys Res Lett. 2013;40:4368-73. doi:10.1002/grl.50834.

63. Song YT, Colberg F. Deep ocean warming assessed from altimeters, Gravity Recovery and Climate Experiment, in situ measurements, and a non-Boussinesq ocean general circulation model. J Geophys Res. 2011;116, C02020. doi:10.1029/2010JC006601.

64. Llovel W, Willis JK, Landerer FW, Fukumori I. Deep-ocean contribution to sea level and energy budget not detectable over the past decade. Nat Clim Chang. 2014. doi:10.1038/nclimate2387. This paper used GRACE, Argo, and altimetry to estimate the rate of recent sea level rise attributable to warming in the ocean below $2000 \mathrm{~m}$. They authors conclude that any warming is not detectable with current observations.

65. Leuliette EW (2014) The budget of recent global sea level rise 2005-2013. 1-10.

66. Miller L, Douglas B. Gyre-scale atmospheric pressure variations and their relation to 19th and 20th century sea level rise. Geophys Res Lett. 2007;34, L16602. doi:10.1029/2007GL030862.

67. Woodworth PL, Pouvreau N, Wöppelmann G. The gyre-scale circulation of the North Atlantic and sea level at Brest. Ocean Sci Discuss. 2009;6:2327-39. doi:10.5194/osd-6-2327-2009.

68. Chepurin GA, Carton JA, Leuliette E. Sea level in ocean reanalyses and tide gauges. J Geophys Res Oceans. 2014;119:147-55. doi:10. 1002/2013JC009365.

69. Roemmich D, Gilson J. The 2004-2008 mean and annual cycle of temperature, salinity, and steric height in the global ocean from the Argo Program. Prog Oceanogr. 2009;82:81-100. doi:10.1016/j. pocean.2009.03.004.

70. Wessel P, Smith WHF, Scharroo R, et al. Generic Mapping Tools: improved version released. Eos Trans AGU. 2013;94:409-10. doi: 10.1002/2013EO450001. 